УДК 82.161.2

DOI: 10.31475/fil.dys.2020.10.05

РОМАН ДУБРОВСЬКИЙ, кандидат ббілологічних наук (л.Кременець)

\title{
Від пацифіста до комбатанта: трансформація свідомості героя в умовах війни (за романом «Віхола» Ю. Мушкетика)
}

У статті представлене дослідження художньої репрезентаиї зміни життевих пріоритетів мирної людини в уловах війни. Зроблено акцент на внутрішніх та зовнішніх колпонентах такої трансборлаиії. На прикладі ролану "Віхола" Ю. Мушкетика розкрито художні особливості візуалізаиї різних типів образу війни. Здійснено узагальнення шодо моделей поведінки мирної людини в незвичнолу для неї "лілітарнолу" часопросторі. Охарактеризовано внутрішні ланки сюжетного каркасу твору з позииї розвитку характерів персонажів. Через конкретні приклади показано та уточнено прогностичний, синхронний і ретроспективний образи війни. Також виділено художні маркери репрезентаиї різних етапів становлення людини-колбатанта. Простежено особливості художнього вираження різних моделей ї̈ поведінки та етапів їх становлення. На основі аналізу тексту роману зроблено висновок про письленницьку майстерність автора, виражену на різних рівнях творення прозописьла (від уління чуттево передати деталізований психологічний портрет, створити психологічно насичені фбілософбські відступи до здатності візуалізувати перехід від "мирного" до "мілітарного" типу свідомості через безпосередній опис екстремальних ситуацій тощо).

Ключові слова: війна, мілітаризл, колбатант, пацифбіст, поліцай.

Постановка проблеми в загальному вигляді... Література про війну надає читачам чимало колоритних образів, характер яких найповніше виявляється саме завдяки екстремальним подіям. Усіх їх можна звести до кількох узагальнених типів: герої, зрадники, просто колаборанти, збайдужілі люди, люди, котрі навпаки виявили в собі гуманність. З одного боку, цей перелік набагато вужчий у порівнянні 3 поліфронізмом людських типів, спроектованих «мирною» літературою, а 3 іншого - у межах саме цих доволі умовних узагальнень 
спостерігається надзвичайно багатий спектр виявів людського «Я» в умовах душевного дисбалансу зображених персонажів. Художня література про війну є різноплановою як у жанровому вияві, так і в контексті сюжето- й образотворення. Однак практично всі твори - i ті, в яких усі акції та емоції героїв пов'язані з батальними сценами, i ті, в яких вони виконують лише атрибутивну роль, - дозволяють осягнути глибину людської витримки, гуманності, психологічної i dрiзичної стійкості, а часто - і трансформацію «маленької людини» у співтворця світової історії (нехай навіть також «маленького»). Війна як зіткнення ворогуючих сил, культур, ідеологій виступає в даному випадку в ролі каталізатора перетворення думки в дію, певною мірою абстрактних поглядів, що повільно дозрівають до переконань, - у конкретну світоглядну позицію, яка штовхае героїв на вчинки. На думку 3. Фройда, вона повертає сучасну людину до стану людини первісної, для якої смерть і вбивство були щоденним явищем, бо «древня історія людства переповнена вбивствами» [5]. Тож література про війну викристалізовуе ті найважливіші людські якості, що складають основу характеру героя, частково абстрагуючись від інших - менш важливих рис. Однак це не призводить до «омертвіння», спотворення чи спрощення образів. Навпаки, війна як ситуація виклику сприяе нашаруванню нових відтінків при творенні портрета того чи іншого персонажа.

Аналіз досліджень $i$ публікацій... Серед дослідників френомену «маленької людини» на фоні «великих» історичних подій можемо виділити таких науковців, як I. Бергер (I. Berger), П. Браянс (P. Brians), Б. М. Боіл (В. M. Boil), В. Волкова, Б. Васильева, І. Захарчук, О. Сенявська, Н. Черкашина, О. Шостак та інших.

Форлулювання цілей статті... Метою написання статті є спроба зробити аналіз трансформації свідомості героїв «мілітарної» (вужче власне воєнної) літератури в екстремальних умовах (на прикладі персонажів роману «Віхола» Юрія Мушкетика) через дослідження еволюції їх світосприйняття i вчинків, вивчення художніх засобів представлення виходу із «зони комфорту».

Виклад основного матеріалу... Роман «Віхола» Юрія Мушкетика, присвячений подіям перших місяців «повзучої» окупації України фашистами, вийшов друком у 1983 році, коли в українській літературі про війну вже давно був встановлений і навіть частково розвінчаний канон зображення подій Другої світової. Тож його герої, аби не розчинитися серед сотень подібних персонажів творів із подібною фабулою, мали набути виразно нових рис і при тому не вийти за рамки 
соцреалістичних типів і загальних постулатів зображення воєнних подій, надиктованих стандартами соціалістичного реалізму. 3 обома завданнями автор впорався. Відтак поза загальними формулами «героя комуніста», «зрадника поліцая» простежується і певне новаторство в розробці сюжету й образів. Так, головний герой Михайло Харченко не $є$ тим, хто безстрашно йде на самопожертву заради Батьківщини чи комуністичної партії. I та, й інша показані нечужими йому, однак він керується радше внутрішнім відчуттям обов'язку перед найближчими людьми, ніж служінням ідеї відновлення радянської влади, частиною якої, фрактично, він і був. Герой мислить, аналізуе, його ненависть поволі визрівае, причому це не ненависть до колаборащіоністів, тому що вони колабораціоністи: вона направлена лише проти тих, кого війна зробила нелюдами.

Наскрізним мотивом твору $е$ мотив кохання. Однак якщо на початку роману це заплутане, не повністю усвідомлене самими героями почуття, то в кінці воно стає потужною силою, яка допомагає їм вижити. Автор проектуе дію так, що саме через любов між Михайлом і Вірою можна простежити визрівання людини-борця із вчорашнього мирного селянина. У душі головного героя це почуття зазнає трансформації: від юнацького захоплення і ревнощів через заперечення будь-якої втіхи в лиху годину до всепереможної сили, здатної побороти найстрашнішу зброю. Так, спочатку Михайла охоплюють ревнощі, коли він підстерігає Віру з іншим: «Михайла бив дрож. Він уявив, як присів у траві Віталій, як зашнуровує черевик, доторкуеться до Віриної ноги, i йому перехопило подих» [2, с. 9]. Але, готуючи себе до поки ще не зовсім зрозумілої саможертовної місії, Харченко вже по-іншому сприймає й любов: «Якщо вже любитесь, то любіться трагічно й жертовно, як тільки й можна любитися в цей час. Він би кохав тільки так. Йому здалося, що він мов би піднісся над ними, адже всі ці дні думав тільки про війну, готував себе до майбутнього подвигу...» [2, с. 21]. Кінець твору, коли загинула головна героїня Віра, розкривае особливості психології людини-комбатанта: «...в ньому жила переконаність, що вони переможуть все. Мабуть, ця певність ішла 3 їхньої любові, йому здавалося, що вона - всесильна, непогасна, більша за світ <..> I ось... Любові нема, а світ стоїть <...> Ця думка знову струснула ним, дві важкі сльози викотилися 3 його очей, скрижаніли на щоках під повівами холодного вітру. Він стер їх долонею, дістав з кишені жменю патронів і повільно почав набивати барабан старого нагана» [2, с. 300301]. Фактично, Михайло повністю сорормувався як боєць лише в кінці твору після смерті коханої. Йдеться, безперечно, не про фрормування 
бійцівських навичок (iх уважний читач може простежити в багатьох попередніх вчинках героя), а про становлення психології бійця, котрий повністю відійшов від іще донедавна звичних для нього моделей поведінки та внутрішніх аксіологічних «стримувачів»: «не зашкодь ближньому», «не убий» тощо. Однак Мушкетик використав такий своерідний художній паралелізм при зображенні визрівання справжньої любові та справжнього усвідомлення своєї бійцівської місії як двох первинних, а відтак, найсильніших людських поривів для загального обрамлення твору. Взагалі, зображення кохання на фоні війни (іноді й війни на фоні кохання) е доволі класичною моделлю художньої нарації, що постає в численних варіантах і модифрікаціях. Новаторство автора в цьому контексті можемо вбачати хіба що в зіставленні «мирного» та "героїчного» кохання на прикладі одних і тих же героїв: 3 одного боку, почуття Михайла доростають до вічності тільки завдяки війні як екстремальному життевому випробуванню, 3 іншого боку, паралельно зображуються його стосунки 3 дружиною, яку він не кохає і яка, однак, готова жертвувати собою заради нього. Лише війна насправді підносить цей «любовний трикутних» на вищий метафізичний рівень. Інакше це була б історія про звичайні стосунки і таку ж звичайну зраду. Однак автор показуе, що колишні почуття поступово завмерли б, якби їх не підживлювала екстремальність воєнного часу. Отже, любов і подвиг стають організуючими елементами художньої дії. Однак важливо простежити також внутрішні ланки сюжетного каркасу твору з позиції розвитку характерів персонажів. Опинившись у новій для себе ситуації, людина природно прагне адаптуватися. У цей процес спочатку залучаються внутрішні зміни як база для можливості подальшої зовнішньої трансформації. Тож коли людина стае причетною до війни як ситуації особистісного вибору одніеї 3 можливих моделей поведінки, вона повільно або швидко починає пристосовуватися до неї, змінюючи пріоритети. При різній динаміці цього процесу, усе ж можемо наголосити на його поступовості, в якій, однак, слід виокремити кілька важливих точок:

1) усвідомлення себе в новій реальності;

2) розуміння власної нездатності самостійно і швидко змінити ситуацію;

3) ламання попередніх ціннісних установок та їх заміна новими, продиктованими ситуацією;

4) перетворення нових аксіологічних орієнтирів у конкретні поведінкові акти.

На основі наведених етапів можна простежити поділ персонажів на 
певні типи. Так, в умовах війни як раніше не відомої екстремальної ситуащії одні герої швидко мобілізують внутрішні сили, а відтак їхне пристосування полягае в усвідомленні нових реалій i прагненні зробити посилений внесок у їх зміну, інші далі продовжують жити звичним життям, сподіваючись, що події самі вкажуть їм на їх місце, треті намагаються зрозуміти зміни й винести 3 цього розуміння максимальну користь для себе. У романі «Віхола» Ю. Мушкетик показуе усі три типи. До першого, зокрема, належать Михайло та Віра, до другого - Михайлова дружина Проня, до третього - усі ті, хто стають найлютішими ворогами головних героїв. Це, в першу чергу, поліцаї, котрі зрадили все те, що колись вважалося найвищими моральними цінностями, і пішли на співпрацю з ворогом шляхом винищення своїх земляків. Війна показана силою, що вносить хаос у традиційне розуміння самою людської психології: «Війна понаплутувала, навихрила, відгадувати людей було до ката важко. Директор передового радгоспу раптом виявився начальником поліції, а запеклий одноосібник, записаний у підкуркульники за те, що довго не хотів вступати до колгоспу, відмовився від посади сільського старости, і його привселюдно відшмагали шомполами» [2, с. 207]. Така ремарка є доволі нетиповою. Згадаймо, для прикладу, навіть Довженкову «Україну в огні», де зрадник-убивця - куркуль Заброда. У Ю. Мушкетика ж з'являеться персонаж Женька, вигнаний свого часу з комсомолу, який шкодить німцям. Повертаючись до згаданих вище типів персонажів, відзначимо, що автор моделюе перший i третій типи героїв взаємозалежними: зрадники допомагають сформувати в патріотів психологію комбатантів, здатних на реальну збройну боротьбу. Важливо простежити момент емоційного зламу, коли «мирна» свідомість героїв перетворюеться на свідомість комбатанта, котрий діє нетипово і здатний на вчинки, які неможливо співвіднести з героєм, який донедавна жив розміреним довоенним життям. У романі «Віхола» це мить, коли головний герой Михайло зважуеться на вбивство свого зрадника-співвітчизника. Проте автор майстерно підводить героїв до миті остаточного протистояння. Так, спочатку Ю. Мушкетик подає відособлені характеристики його учасників. Поліцая Юхима автор характеризуе його ж словами: «Я не люблю, коли отако: чухи-чухи за вухом, а тоді - швайкою під ребро. Люблю сопротівленіє» [2, с. 161]. А потім додае ремарку: «Михайлові аж у горлі запекло, хотілося запитати: чого стріляв людей у спину, наледве стримався» [2, с. 161]. Характеризуючи самого Михайла, Ю. Мушкетик показуе перший момент психологічного зламу - розуміння того, що вчинення вбивства $€$ 
природною необхідністю (раніше герой такою необхідністю міг вважати тільки життя): «Жорстокість текла в Юхимових жилах разом з кров’ю, проте Михайло не почував страху та й здогадувався, що показувати того не можна. I в ту ж мить відчув, що в ньому самому народилося тверде рішення, народилася неминучість, і він не може не звершити того, що враз визріло в ньому як присуд долі» [2, с. 161]. Далі письменник зводить характеристики суперників в одне ціле, проте залишає їх на протилежних сторонах ціеї єдності. Така антитеза створюе психологічну напругу, згущуе наративну динаміку. Для прикладу: «Юхим подивився на годинник, підвівся. Годинник у нього ручний, іноземний. I Михайло дістав свій годинник - ще батьків цибулину. Здавалося, кожен з них звіряв свій час. Та так воно й було насправді» [2, с. 162].

Наступним елементом формування психології комбатанта $е$ перехід від думок до вчинків. Цікаво, що Ю. Мушкетик більш ретельно описував саме емоційний злам героя, аніж момент убивства ним ворога, після якого автор знову ж таки зосереджуеться на психологічному портреті героя: «Гримнув постріл. У клубкові полум'я Михайло встиг побачити чорний крутий схил яру і велику - велетенську, - круглу голову Юхима. <...> Щось тихо, тихо і страшно сказало йому, що він убив людину. I в ту ж мить відчув, що він убив щось у собі. Не шкодував, що вбив Юхима, навпаки, це було неминуче, він ще тоді, розмовляючи 3 ним, зрозумів це, воно й виникло як неухильність, неминучість, тільки не знав, що вб’є щось і в собі, й за це розсердився на вже мертвого Юхима» [2, с. 168].

У романі описано багато подій, де герої псують майно, призначене ворогові, шкодять налагодженню зв'язку, ризикуючи бути схопленими, організовують роботу підпільного загону, роздають листівки, мандрують із фральшивими документами, обманюють тощо. Однак все це мотивується або потребою самозбереження, або почуттям обов'язку перед громадою i майже ніколи не пов'язане 3 необхідністю власноручного завдання насильства. Більше того, автор вдаеться до протиставлення головного героя Михайла, розважливого, гуманного, та його позиційного товариша Женька, здатного на необдумані витівки заради підняття рівня адреналіну в крові («- Ти більше не роби нічого сам, - сказав Женькові Михайло. - А хіба що? - кинув п'ятірнею на лоба кучері Женько. - Поранили поліцаєвого батька. Під суворим Михайловим поглядом він трохи знітився, йому стало досадно... [2, с. 187]»). Зрештою, після описаного вище переломного моменту (перше «необхідне» Михайлове вбивство ворога) перед читачами постає інший 
тип героя-воїна. Він готовий холоднокровно використати зброю, щоб захистити себе i, що важливо, завдати втрат ворогові. Помста стає важливим елементом життя персонажа, проте про шляхи ії реалізації читач може лише здогадуватися, оскільки автор практично завершуе розповідь на моменті визрівання героя-месника, трансформованого 3 героя-жертви («Вона [любов - Р. Д.] й надалі залишиться з ним, але вже тільки жаданням помсти, боротьбою. А коли все скінчиться... Він не міг помислити, що тоді станеться з ним і для чого він житиме» [2, с. 300]). До речі, у цьому контексті можна й простежити відстань між психологією жертви і психологією жертовності. У першому випадку герой намагається втекти від війни як стихії, можливо, десь перехитрити обставини, заховатися, перечекати нелегкі часи, у другому ж він свідомо протистоїть переважаючій силі, кидає їй виклик, розуміючи, що це може призвести до самознищення. Саме ці орієнтири є відправною та кінцевою точками в еволющіі свідомості Михайла. Фактично, йдеться про визрівання самодостатнього «я», здатного протистояти силі, що складається з маленьких нікчемних елементів великого «ми», котрі хочуть мати бодай якусь владу над іншими людьми. Якщо у мирний час в них не було жодного шансу отримати іï, то війна таку можливість надала, щоправда, через набуття статусу складової спільної мілітарної машини. С. Белов наголошує: «Фашизм не доктрина, створена кабінетними вченими, схвалена в верхах i спущена вниз пересічним громадянам для виконання. Фашизм демократичний, народжується 3 невдоволення пересічних громадян, коли це саме невдоволення, стикаючись із корупціею та безсиллям соціальних інститутів і підігріваючись бажанням скоріше обміняти своє нікчемне пустеньких "я» на сталеве і переможне «ми», висікае іскри, здатні роздути світову пожежу» [1, с. 168]. Не належачи до жодного колективного «ми», головні герої усе ж починають партизанську боротьбу, спочатку не маючи жодних підривних чи військових навичок, не розуміючи їі спещифіки. Проте війна як ситуащія зламу побутовокультурних та, глибше, психологічних оріентирів підштовхуе їх до пошуку шляхів реалізації боротьбистських інтенцій.

Також при поступовому формуванні психологічного портрета комбатанта можемо простежити й за динамікою образу війни. Так, О. Сенявська виділяе 3 типи цього образу: 1) прогностичний; 2) синхронний; 3) ретроспективний [4, с. 45]. На початку роману всі герої сприймають війну як щось загрозливе й одночасно незрозуміле. Вона повільно вриваеться в мирне життя, ламає його усталені століттями традиції, але до того проникає в свідомість людей, котрі не 
знають, із чим їм доведеться мати справу. А все незрозуміле природно викликає страх: «Село жило. Люди поралися в померках, звуки були невеселі і скрадливі. Кожному здавалося, буцім його можуть почути аж звідтам, з-за Дніпра, або й з другого кінця землі. Тепер кожен звук мав інше значення, інший смисл» [2, с. 8]. Традиційно прогностичний образ війни є широким, неконкретним, неначе люди дивляться на неї здалеку i можуть розпізнати лише найзагальніші обриси. Він $є$ емоційним та, знову ж таки традиційно, не зовсім адекватним. Людина, котра звикла до праці і миру, не може швидко зорієнтуватися в тому, чим $є$ війна. Але для неї характерний природний страх смерті, яка поки стає єдиною асоціацією із війною. Тож спрацьовуе лише перша частина твердження Сенеки про те, що «людина боїться не смерті, а думок про смерть, тому про неї потрібно постійно міркувати, щоб привчити свідомість до спокійного сприйняття смерті» [3, с. 80]. Ціеї позиції й дотримуеться Ю. Мушкетик у «Віхолі». На зміну прогностичному приходить синхронний образ. Він подається завдяки різним засобам. Так, автор показуе зміну характерів героїв. Вони із наївних переляканих пацифістів перетворюються на миролюбних реалістів, котрі розуміють, що на війні необхідно бути готовими до будь-якого перебігу подій і тому слід стати більш практичними. Тож Михайло показаний не лише в абстрактних роздумах, але i в діяльності, необхідній в мілітаризованому світі навколо нього. Для прикладу: «Михайло поставив на коліно приклад гвинтівки, відкрив затвор і по одному патрону, натискаючи зверху великим пальцем, втопив в обойму. Закрив затвор, звернув управо курок, звівши гвинтівку на запобіжник» [2, с. 239]. Автор показуе головного героя морально налаштованим на насильство, якщо його вимагатиме ситуація, власне, війна. Однак синхронний образ вимагае від письменника не лише представлення зміни в портретах головних героїв чи їх діях. Війна завжди охоплюе широкі маси. Це не одиничне насильство, хоча, за винятком боїв безпосередньо на фронті, вона складаеться з тисяч таких одиничних актів. Представлення війни як масштабної події в темпоральній i просторовій проекції забезпечуеться візуалізацією завдяки найрізноманітнішим художнім засобам окремих ситуацій та персонажів (військових, цивільних), які автор моделюе як типові. Ю. Мушкетик, проектуючи синхронний образ війни, показуе жорстокість і гуманізм як дві сили, здатні до найповнішого вияву саме в екстремальній ситуації. Зокрема, письменник зображуе жорстокість зрадників-поліцаїв: «Вже по обіді поліцаї взяли у когось з рибалок човен, витягли Віталія й повісили вже мертвого, задубілого на яблуні. 
На тій самій, під якою стояв колись 3 Вірою, зашнуровував їй черевички. Під яблунею його й закопали» [2, с. 180]. Але війна є й можливістю для вияву гуманності. Це також показуе автор, роблячи філософські висновки: «Часом до однієї хати набивалося на ночівлю по десять, а то й більше чоловік. Над усіми тими людьми - простерлася величезна натруджена згорьована рука - рука милосердя, ще ніколи люди не стояли так щільно одне до одного, ще ніколи людина не брала так близько до серця чужу біду. <..> Ті спочутливість і доброта просто вражали... Так само, як черствість і жорстокість. Правду кажуть: одним і тим же сірником можна запалити свічку перед іконою і спопелити хату" [2, с. 208].

До ретроспективного образу війни письменник звертається лише в післямові. Читач не бачить його очима персонажів, а лише через окремі узагальнюючі авторські ремарки, пов'язані 3 головним героєм Михайлом, котрий мав реальний прототип, про якого літератор зізнається тільки на цих останніх сторінках роману.

Висновки з описаного дослідження $i$ перспективи подальших розвідок у данолу напрялі... Можемо зробити висновок про те, що перехід від спокою мирного життя до сподвижницької боротьби за право на власне життя та життя прийдешніх поколінь завжди бере початок на внутрішньому - психологічному рівні, у людських головах, а тільки потім утілюється в реальних вчинках. Така трансформація завжди була цікавою для письменників - обсерваторів людських типів. Не винятком є і Ю. Мушкетик. Письменник у романі «Віхола» майстерно репрезентує - на рівні психологічного портрета, фрілософрських відступів, безпосереднього опису екстремальних ситуацій тощо - формування людини-борця, яка, перейшовши на «мілітарний» тип свідомості, мислення, емоційної стабільності, вчинків, усе ж зберігае власне гуманне, чуйне, сповнене любові до ближнього осердя. Така література насправді е художньо-науковими студіями, присвяченими дослідженню меж людяності, безвідносних до часу та обставин.

\section{Список використаних джерел і літератури:}

1. Белов С. Б. Бойня номер «Х»: Литература Англии и США о войне и военной идеологии / С. Б. Белов. - М. : Советский писатель, 1991. - 368 с.

2.Мушкетик Ю. М. Віхола: роман / Ю. М. Мушкетик. - К. : Молодь, 1983. $304 \mathrm{c}$.

3. Сенека. Нравственные письма к Луцилию // Сенека и др. Если хочешь быть свободным. Москва : Политиздат, 1992. С. 7-110.

4. Сенявская Е. С. Психология войны в XX веке: исторический опыт России 
/ Е. С. Сенявская. - М. : РОССПЭН, 1999. - 384 с.

5.Фрейд, 3. Мы и смерть. По ту сторону принципа наслаждения / 3. Фрейд ; пер. Е. Баевской, Л.А. Голлербах. Санкт-Петербург : ВосточноЕвропейский Институт Психоанализа, 1994. 382 с. [Електронний ресурс]. Режим доступу : http://osp.kgsu.ru/library/PDF/397.pdf.

\section{References:}

1. Belov S. B. Bojnja nomer "X»: Lyteratura Anghlyy y SShA o vojne y voennoj ydeologhyy / S. B. Belov. - M. : Sovetskyj pysatelj, 1991. - 368 s.

2. Mushketyk Ju. M. Vikhola: roman / Ju. M. Mushketyk. - K. : Molodj, 1983. $-304 \mathrm{~s}$.

3. Seneka. Nravstvennore pysjma k Lucylyju // Seneka y dr. Esly khocheshj bыtj svobodnыm. Moskva : Polytyzdat, 1992. S. 7-110.

4. Senjavskaja E. S. Psykhologhyja vojnы v KhKh veke: ystorycheskyj орыt Rossyy / E. S. Senjavskaja. - M. : ROSSPЭN, 1999. - 384 s.

5. Frejd, Z. Мы у smertj. Po tu storonu pryncypa naslazhdenyja / Z. Frejd ; per. E. Baevskoj, L.A. Ghollerbakh. Sankt-Peterburgh : Vostochno-Evropejskyj Ynstytut Psykhoanalyza, 1994. 382 s. URL : http://osp.kgsu.ru/library/PDF/397.pdf.

\section{Summary \\ Roman Dubrovskiy \\ From Pacifist to Combatant: Transformation of the Consciousness of the Hero in the Conditions of War}

\section{(According to Novel "Vihola" ("Whirlwind») by Yu. Mushketyk)}

The article presents the study of artistic representation of changing the life priorities of a peaceful man in the conditions of war. The emphasis is placed on the internal and external components of such a transformation. On the example of the novel "Vihola" ("Whirlwind") by Yu. Mushketyk there are revealed the artistic features of visualization of various types of the image of war. It is made the generalization of the behavior patterns of a civilians in a "militaristic" time-space that is unusual for them. The internal links of the story frame of the literary work are characterized from the point of view of character development. On the basis of the specific examples there were shown and refined the prognostic, synchronous and retrospective images of the war. Artistic markers of representation of different stages of becoming a human-combatant has been also highlighted. The features of artistic expression of different models of their behavior and stages of their formation has been traced. Based on the analysis of the text of the novel, it is concluded about the author's writing skills, expressed at different levels of writing creation (from the ability of sensuall convey of a detailed psychological portrait, to creation of psychologically rich philosophical retreats and ability of visualization of the transition from "peaceful» without "militaristic» type of consciousness through direct description of extreme situations, etc.).

Key words: war, militarism, combatant, pacifist, policeman.

Дата надходження статті: «28» жовтня 2019 р.

Дата прийняття до друку: «05» грудня 2019 р. 